\title{
Determination of heavy metals and their availability to plants in soil fertilized with different waste substances
}

\author{
Jadwiga Wierzbowska • Peter Kovačik • \\ Stanisław Sienkiewicz • Slawomir Krzebietke • \\ Teresa Bowszys
}

Received: 6 October 2017 / Accepted: 22 August 2018/Published online: 3 September 2018

(C) The Author(s) 2018

\begin{abstract}
Field trials were conducted in 2004-2015, in Bałcyny, on haplic Luvisol formed out of light boulder clay. The experiment consisted of the following treatments: control (no fertilization), NPK, manure (FYM), dried pelleted sewage sludge (DPSS), composted sewage sludge (CSS), compost made from municipal sewage sludge and straw (SSCS), compost Dano made from unsorted household waste (CUHW), and compost produced from urban green waste (CUGW). Over a period of 12 years, $30 \mathrm{t} \mathrm{DM/ha}$ of each manure and composts were used, that is, $10 \mathrm{t} \mathrm{DM} / \mathrm{ha}$ in each rotation of a crop rotation sequence. Nitrogen fertilization was kept on the same level on all experimental plots. Soil samples from the 0 - to $20-\mathrm{cm}$ horizon were collected after the third rotation crop, which was winter wheat harvested in 2015. It has been demonstrated that CUHW raised the soil total $\mathrm{Cu}$ content the highest, while the soil content of $\mathrm{Zn}$ was elevated the most by DPSS. The content of the remaining heavy metals $(\mathrm{Pb}, \mathrm{Ni}, \mathrm{Cr}, \mathrm{Mn}$, and $\mathrm{Fe})$ increased as well, but to a lesser extent. The soil abundance of phytoavailable forms of copper improved even
\end{abstract}

J. Wierzbowska $(\bowtie) \cdot$ S. Sienkiewicz $\cdot$ S. Krzebietke •

T. Bowszys

Chair of Agricultural Chemistry and Environmental Protection, Faculty of Environmental Management and Agriculture, University of Warmia and Mazury in Olsztyn, 10719 Olsztyn,

Poland

e-mail: jadwiga.wierzbowska@uwm.edu.pl

P. Kovačik

Department of Agrochemistry and Plant Nutrition, Faculty of

Agrobiology and Food Resources, Slovak University of

Agriculture in Nitra, 94901 Nitra, Slovakia greater (from $75 \%$ when fertilized with CUGW or CSS, up to $124 \%$ when treated with CUHW). Soil content of soluble forms of such metals as $\mathrm{Zn}, \mathrm{Pb}, \mathrm{Cr}, \mathrm{Mn}$, and $\mathrm{Fe}$ changed less. The content of all analyzed heavy metals in soil (a form approximating the total content) was significantly positively correlated with the content of organic carbon (C-org.). This is the evidence for stronger adsorption of the above elements in soil richer in organic matter. On the other hand, the content of available forms of heavy metals depended more on the soil $\mathrm{pH}$ than on its content of C-org.

Keywords Composted sewage sludge $\cdot$ Municipal compost $\cdot$ Heavy metals $\cdot$ Soil $\cdot$ Waste organic materials

\section{Introduction}

With continually growing amounts of municipal sewage sludge, the problem of how to recycle this waste gains an ever greater importance. Sewage sludge is a noxious but unavoidable by-product of wastewater and sewage treatment. According to data supplied by the Polish Central Statistical Office, 568 thousand tonnes DM of sewage sludge were generated in Poland in 2015, of which 107.5 thousand DM t were used in agriculture (Environment 2016). Sewage sludge is also employed for remediation of degraded land (19.2 thousand DM t) and cultivation of plants grown for composting (47.1 thousand DM t). In the same year, 10.9 million tonnes of municipal waste were collected, of which $16 \%$ was recycled by composting. 
Sewage sludge and sewage sludge composts are a valuable source of organic matter and nutrients. One of the most rational ways of sewage sludge utilization, especially after the waste has been composted, is to apply it in agriculture (Bowszys et al. 2009; Wieczorek and Fraczek 2013). In the study of Kluczka et al. (2017), it is written that soils in Poland are not contaminated with heavy metals. According to the authors, this is an argument for the optimistic thing on the use of sludge in agriculture. Sewage sludge and sewage sludge composts intended to be returned to the natural environment must meet numerous safety requirements so as not to cause pollution (Regulation of the Minister ... 2015; Introduction of Fertilizers ... n.d.). As civilization progresses, more and more waste is generated and its chemical composition changes. Depending on the origin, waste can contain considerable quantities of harmful substances, including heavy metals or PAHs, in addition to which it can be contaminated by microorganisms and parasites (Wieczorek and Frączek 2013; Milinovic et al. 2014). An assessment of the bioavailability of heavy metals based exclusively on their total content in sewage sludge may be insufficient to make an informed decision about its application in agriculture. The content of heavy metals in sewage sludge does not resolve unambiguously the question of their potential uptake by plants (Gawdzik and Gawdzik 2012; Fadiran et al. 2014; Tytła et al. 2016). A speciation analysis enables us to gain broader knowledge and understanding of the mobility and bioavailability of various fractions of metals and therefore substantiates a more rational decision to use sewage sludge for agricultural purposes. An in-depth and comprehensive insight into the ecological consequences of soil enrichment with sewage sludge composts requires basic and experimental studies, which will generate data for the development of rational and safe use of such products.

The aim of this study has been to assess the impact of sewage sludge and sewage sludge composts on the content of total and mobile forms of selected heavy metals in soil.

\section{Material and methods}

A field experiment was conducted in 2004-2015, in Bałcyny (53 $35^{\prime} 49^{\prime \prime} \mathrm{N} 19^{\circ} 51^{\prime} 20^{\prime \prime} \mathrm{E}$ ), on haplic Luvisol formed out of light boulder clay (WRB 2015). The field trials comprised three crop rotation sequences: potato, spring barley, winter oilseed rape, winter wheat. Selected soil properties prior to the experiment are collated in Table 1.

The experiment consisted of the following treatments: control (no fertilization), NPK, manure (FYM), dried pelleted sewage sludge (DPSS), composted sewage sludge (CSS), compost made from municipal sewage sludge and straw (SSCS), compost Dano made from unsorted household waste (CUHW), and compost produced from urban green waste (CUGW). Fertilization treatments during the experiment were composed of $30 \mathrm{t}$ $\mathrm{DM} /$ ha of manure or composts, i.e., $10 \mathrm{t} \mathrm{DM/ha} \mathrm{applied}$ after each rotation crop. Nitrogen fertilization was on the same level in all treatments, namely in the years when organic materials were applied, a dose of $\mathrm{N}$ up to the recommended level for the fertilized crop was supplemented with mineral fertilizers. In the remaining years, only mineral fertilization was applied. Soil samples from each plot (ten individual punctures from each plot were a pooled sample) were collected using Egner's sampling stick, from the 0 - to 20 -cm soil layer after the third rotation was over, i.e., after harvesting winter wheat in 2015.

The chemical analyses of soil were performed with methods generally used in agricultural analytical chemistry. Soil reaction $(\mathrm{pH})$ was determined potentiometrically in potassium chloride solution $\left(1 \mathrm{~mol} \mathrm{KCl} / \mathrm{dm}^{3}\right)$ and hydrolytic acidity $(\mathrm{Hh})$ was determined using the Kappen method. Quantities approximating to total content of heavy metals in soil were extracted in a mixture of perchloric and nitric acids (Ostrowska et al. 1991),

Table 1 Characteristics of soil at the beginning of the experiment

\begin{tabular}{lllr}
\hline Component & & Unit & Content \\
\hline C-organic & & $\mathrm{g} / \mathrm{kg}$ & 7.63 \\
N-total & & $\mathrm{g} / \mathrm{kg}$ & 0.64 \\
$\mathrm{pH} 1 \mathrm{~mol} \mathrm{KCl} / \mathrm{dm}^{3}$ & & - & 5.40 \\
$\mathrm{Hh}$ & & $\mathrm{mmol}(+) / \mathrm{kg}$ & 27.7 \\
Available forms & $\mathrm{P}$ & $\mathrm{mg} / \mathrm{kg}$ & 45.1 \\
& $\mathrm{Cu}$ & $\mathrm{mg} / \mathrm{kg}$ & 1.47 \\
& $\mathrm{Zn}$ & $\mathrm{mg} / \mathrm{kg}$ & 10.11 \\
& $\mathrm{Mn}$ & $\mathrm{mg} / \mathrm{kg}$ & 104.50 \\
& $\mathrm{~Pb}$ & $\mathrm{mg} / \mathrm{kg}$ & 9.90 \\
& $\mathrm{Cr}$ & $\mathrm{mg} / \mathrm{kg}$ & 0.61 \\
& $\mathrm{Ni}$ & $\mathrm{mg} / \mathrm{kg}$ & 0.75 \\
& $\mathrm{Fe}$ & $\mathrm{mg} / \mathrm{kg}$ & 1280 \\
\hline
\end{tabular}


and the available forms were extracted in $1 \mathrm{~mol} \mathrm{HCl} /$ $\mathrm{dm}^{3}$ (Karczewska and Kabała 2008). The content of heavy metals was determined with the atomic absorption spectrometric method (AAS) on a Shimadzu AA6800 apparatus. The share of mobile forms of heavy metals to their total content in soil was calculated according to the formula shares of forms soluble in $1 \mathrm{~mol}$ $\mathrm{HCl} / \mathrm{dm}^{3}$

\%of forms soluble in $1 \mathrm{~mol} \mathrm{HCl} / \mathrm{dm}^{3}$

$$
=\frac{\text { content of forms soluble in } 1 \mathrm{~mol} \mathrm{HCl}}{\text { total content of heavy metal }} \times 100
$$

The content of dry matter in organic materials was determined with the gravimetric (over drying and weighing) method (PN-EN 15934:2013-02E), while the content of organic carbon was determined after dry mineralization in a muffle furnace at $520{ }^{\circ} \mathrm{C}$ (PN-EN 15936:2013-02E) and that of total nitrogen with the Kjeldahl's method after mineralization in concentrated sulfuric acid. The content of heavy metals in manure and composts was determined with the atomic absorption spectrometric (AAS) method on a Shimadzu AA-6800, after wet mineralization in a 4:1 mixture of nitric and chloric acids with added $\mathrm{HCl}$. The determinations were completed by referring to certified material (Trace Metals-Sewage Sludge 4, Sigma-Aldrich RTC, Inc.), Table 2.

The results of chemical analyses were processed statistically in Statistica $12^{\circledR}$. Verification of the significance of differences between the data was supported by the Tukey's test at a level of significance equal $\alpha=0.05$. Cluster analysis was made by agglomerative clustering (single-element clusters), and the Euclidean distance served as a metric of disagreement.

\section{Results and discussion}

The tested organic materials applied to fertilize soil differed not only in the content of dry matter and organic matter, but also in content of heavy metals (Table 3). Compared to manure (FYM), compost made from urban green waste $(\mathrm{CUGW})$ contained less copper $(\mathrm{Cu})$ and zinc ( $\mathrm{Zn}$ ) (by 7 and 40\%, respectively), and all composts and sewage sludge were less abundant in manganese $(\mathrm{Mn})$. Composts and sewage sludge, however, contained higher amounts of the remaining heavy metals than manure.

Immobile fractions of heavy metals in stabilized sewage sludge prevail over their mobile forms. Thickening, stabilization, and hygienization of sewage sludge decrease the mobility of these elements (increasing the content of dry matter during the consecutive processing stages). This limits the migration of heavy metals from sewage sludge to soil solution as well as their accumulation in living organisms (Tytła et al. 2016). Drying sewage sludge before its incorporation in soil typically decreases the leaching of $\mathrm{Zn}$ while increasing that of $\mathrm{Cu}$ (Milinovic et al. 2014). However, it should be borne in mind that heavy metals immobilized in the oxidizable fraction may be a potential threat to the soil's zone of aeration (Gawdzik and Gawdzik 2012).

The content of heavy metals in the soil, as well as other elements, depends in the first place on the parent rock. The total content of the analyzed elements in Polish soils is quite strongly diversified and amounts to the following: $\mathrm{Cu} 4-36, \mathrm{Zn} 30-360, \mathrm{Mn} 50-1400, \mathrm{~Pb}$ 13-52, Ni 10-104, Cr 14-80, and Fe from 8000 to $27,800 \mathrm{mg} / \mathrm{kg}$ (Kabata-Pendias and Pendias 1999). Taking into consideration the above data, it should be stated that the content approximating to total content of heavy metals in analyzed soil did not exceed the range of natural content. The data presented in Fig. 1 show that, after the third crop rotation was terminated, the smallest quantities of the selected heavy metals, except Mn, were

Table 2 The determinations referring to certified material (Trace Metals-Sewage Sludge 4, Sigma-Aldrich RTC, Inc.)

\begin{tabular}{lllllllll}
\hline Value of determination & \multicolumn{2}{l}{ The content of heavy metals in Sewage Sludge 4} & & \\
\cline { 2 - 8 } & $\mathrm{Cu}$ & $\mathrm{Pb}$ & $\mathrm{Ni}$ & $\mathrm{Cr}$ & $\mathrm{Zn}$ & $\mathrm{Mn}$ & $\mathrm{Fe}$ \\
\hline Certified value (mg/kg DM) & $482 \pm 50.4$ & $154 \pm 12.4$ & $163 \pm 13.5$ & $289 \pm 30.4$ & $1240 \pm 181$ & $693 \pm 108$ & $20,100 \pm 4390$ \\
Determination value (mg/kg DM) & 455.5 & 153.2 & 160.8 & 280.9 & 1075.6 & 615.2 & 22,398 \\
Precision of determination (\%) & 94.5 & 99.5 & 98.7 & 97.2 & 86.7 & 88.8 & 111.4 \\
\hline
\end{tabular}


Table 3 Selected chemical characteristics of organic materials tested in the experiment

\begin{tabular}{|c|c|c|c|c|c|c|}
\hline Component & $\begin{array}{l}\text { Manure } \\
\text { (FYM) }\end{array}$ & $\begin{array}{l}\text { Dried pelleted } \\
\text { sewage sludge } \\
\text { (DPSS) }\end{array}$ & $\begin{array}{l}\text { Composted } \\
\text { sewage } \\
\text { sludge (CSS) }\end{array}$ & $\begin{array}{l}\text { Compost made from } \\
\text { municipal sewage sludge } \\
\text { and straw (SSCS) }\end{array}$ & $\begin{array}{l}\text { Compost "Dano" made } \\
\text { from unsorted household } \\
\text { waste (CUHW) }\end{array}$ & $\begin{array}{l}\text { Compost produced } \\
\text { from urban green } \\
\text { waste }(\mathrm{CUGW})\end{array}$ \\
\hline \multicolumn{7}{|l|}{$\mathrm{g} / \mathrm{kg} \mathrm{DM}$} \\
\hline DM & 266.4 & 203,1 & 851.4 & 560.0 & 647.0 & 811.0 \\
\hline C-org. & 231.2 & 388.9 & 428.8 & 170.7 & 152.9 & 65.9 \\
\hline $\mathrm{C} / \mathrm{N}$ & 13.1 & 7.0 & 6.7 & 8.4 & 15.3 & 6.6 \\
\hline P-tot. & 1.0 & 10.4 & 8.0 & 4.4 & 2.9 & 3.2 \\
\hline \multicolumn{7}{|l|}{$\mathrm{mg} / \mathrm{kg} \mathrm{DM}$} \\
\hline $\mathrm{Cu}$ & 36.8 & 402.0 & 249.0 & 65.5 & 297.0 & 34.1 \\
\hline $\mathrm{Zn}$ & 223.0 & 980.0 & 1360.0 & 295 & 831.0 & 133.0 \\
\hline $\mathrm{Mn}$ & 334.0 & 228.0 & 300.5 & 210.6 & 273.6 & 326.8 \\
\hline $\mathrm{Pb}$ & 5.50 & 15.8 & 20.3 & 24.9 & 178.0 & 29.1 \\
\hline $\mathrm{Cr}$ & 10.20 & 56.90 & 33.20 & 15.3 & 53.7 & 19.8 \\
\hline $\mathrm{Ni}$ & 6.64 & 28.0 & 36.6 & 17.7 & 35.2 & 15.5 \\
\hline $\mathrm{Fe}$ & 3340 & 15,590 & 11,260 & 8050 & 16,200 & 5197 \\
\hline
\end{tabular}

determined in soil of the control treatment $(\mathrm{Cu} 4.25, \mathrm{Zn}$ 15.04, Mn 189.84, Fe 4349.74, Pb 14.60, Ni 6.66, and Cr $12.36 \mathrm{mg} / \mathrm{kg}$ ). Fertilization with NPK mineral fertilizers, manure, and other organic materials tended to increase in the soil the quantities approximating to total content of heavy metals. Compared to the control treatment (total content of $\mathrm{Cu}$ and $\mathrm{Zn}, 4.25$ and $15.04 \mathrm{mg} / \mathrm{kg}$, respectively), the soil fertilized with compost from unsorted household waste (CUHW) had a content of $\mathrm{Cu}$ higher by $57 \%$, and the soil treated with dried pelleted sewage sludge (DPSS) contained 35\% more $\mathrm{Zn}$. The content of the other heavy metals changed within a smaller range composted sewage sludge (CSS) favored the accumulation of total content of Mn $(199.86 \mathrm{mg} / \mathrm{kg})$, and compost produced from unsorted household waste (CUHW) and manure (FYM) increased the total content of Fe in soil (4843.8 and $4833.0 \mathrm{mg} / \mathrm{kg}$, respectively). Among the elements which do not belong to plant nutrients, most $\mathrm{Pb}(17.00 \mathrm{mg} / \mathrm{kg})$ was found in soil fertilized with CUGW (over 16\% more than in the control soil), and $\mathrm{Ni}(7.97 \mathrm{mg} / \mathrm{kg})$ was most abundant in soil fertilized with CSS ( $c$ a 20\% than in control), while the soil fertilized with DPSS or CUHW was $c a$ $25 \%$ richer in $\mathrm{Cr}$ (15.41 and $15.29 \mathrm{mg} / \mathrm{kg}$, respectively) than in the control soil.

The content of all analyzed heavy metals in soil was significantly positively correlated with the organic carbon (C-org.) and phosphorus total (P-tot.) content (Table 4). The strongest correlation coefficients between
C-org. contents were demonstrated with respect to the content of $\mathrm{Cu}\left(r=0.74^{*}\right), \mathrm{Cr}\left(r=0.63^{*}\right)$, and $\mathrm{Zn}(r=$ $\left.0.59^{*}\right)$, while slightly weaker in relation to $\mathrm{Fe}(r=$ $\left.0.45^{*}\right), \mathrm{Pb}(r=0.42 *), \mathrm{Ni}\left(r=0.31^{*}\right)$, and $\mathrm{Mn}\left(0.29^{*}\right)$. At the same time, the content of $\mathrm{Cr}\left(r=0.43^{*}\right), \mathrm{Cu}(r=$ $\left.0.35^{*}\right), \mathrm{Ni}\left(r=0.29^{*}\right)$, and $\mathrm{Pb}\left(r=0.21^{*}\right)$ was positively correlated with the content P-tot. in soil. Significant and positive correlation coefficients were also determined for the content of $\mathrm{Cu}\left(r=0.57^{*}\right), \mathrm{Fe}\left(r=0.47^{*}\right), \mathrm{Zn}$ $\left(r=0.33^{*}\right), \mathrm{Cr}\left(r=0.24^{*}\right)$, and $\mathrm{Pb}\left(r=0.22^{*}\right)$ versus the soil pH. The total content of $\mathrm{Cr}\left(r=0.53^{*}\right), \mathrm{Cu}$ $\left(r=0.44^{*}\right), \mathrm{Zn}$ and $\mathrm{Fe}\left(r=0.41^{*}\right)$, and $\mathrm{Ni}\left(r=0.40^{*}\right)$ was positively correlated with the sorption complex capacity. Finally, the content of $\mathrm{Cu}(r=-0.42 *), \mathrm{Fe}$ $\left(r=-0.37^{*}\right), \mathrm{Pb}\left(r=-0.33^{*}\right)$, and $\mathrm{Cr}\left(r=-0.41^{*}\right)$ was negatively correlated with the hydrolytic acidity of soil.

Presence of stabilized, insoluble organic matter in soil, containing high molecular humic acids, induces permanent binding of heavy metals and their immobilization. Low molecular organic substances, that is, organic acids, polyphenols, and fulvic acids, cause either complexing or chelating of heavy metals, and the resulting bonds are characterized by high mobility in the soil environment (Wu et al. 2003; Park et al. 2011).

The contents of the determination heavy metals soluble in $1 \mathrm{~mol} / \mathrm{dm}^{3}$ were found in the control soil in the following amounts: $\mathrm{Cu} 1.61, \mathrm{Zn} \mathrm{11.16,} \mathrm{Mn} \mathrm{107.48,} \mathrm{Fe}$ 1220.55, Pb 8.14, Ni 0.77, Cr 0.66 mg/kg (Fig. 2). 

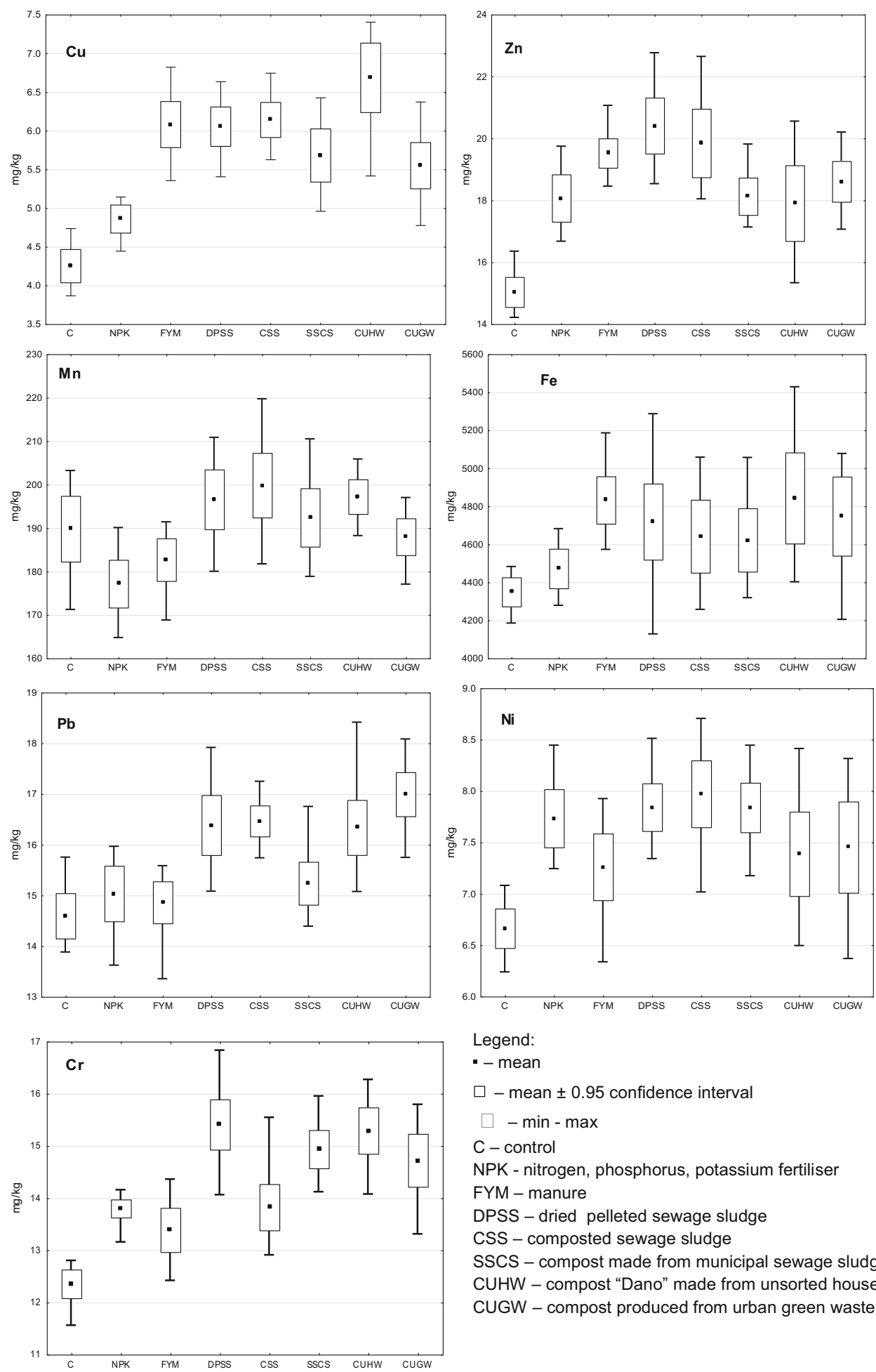

Legend:

- - mean

$\square-$ mean \pm 0.95 confidence interval

$\square-\min -\max$

C - control

NPK - nitrogen, phosphorus, potassium fertiliser

FYM - manure

DPSS - dried pelleted sewage sludge

CSS - composted sewage sludge

SSCS - compost made from municipal sewage sludge and straw CUHW - compost "Dano" made from unsorted household waste CUGW - compost produced from urban green waste

Fig. 1 Content of heavy metals in soil (quantities approximating to the total content). Legend: - mean, $\square$ mean \pm 0.95 confidence interval, min-max, C control, NPK nitrogen, phosphorus, potassium fertilizer, FYM manure, DPSS dried pelleted sewage sludge,

CSS composted sewage sludge, SSCS compost made from municipal sewage sludge and straw, CUHW compost "Dano" made from unsorted household waste, CUGW compost produced from urban green waste 
Table 4 Correlations coefficient $r$ between selected soil properties and the content of heavy metals in soil (content approximating to total)

\begin{tabular}{|c|c|c|c|c|c|c|c|}
\hline \multirow[t]{2}{*}{ Selected soil properties } & \multicolumn{7}{|c|}{ Content of heavy metals in soil } \\
\hline & $\mathrm{Cu}$ & $\mathrm{Zn}$ & $\mathrm{Mn}$ & $\mathrm{Fe}$ & $\mathrm{Pb}$ & $\mathrm{Ni}$ & $\mathrm{Cr}$ \\
\hline $\mathrm{pH}$ & $0,57 *$ & $0.33 *$ & 0.07 & $0.47 *$ & $0.22 *$ & -0.02 & $0.24^{*}$ \\
\hline C-org. & $0.74 *$ & $0.59 *$ & $0.29 *$ & $0.45^{*}$ & $0.42 *$ & $0.31 *$ & $0.63^{*}$ \\
\hline P-tot. & $0.35^{*}$ & 0.13 & 0.10 & 0.10 & $0.21 *$ & $0.29 *$ & $0.43^{*}$ \\
\hline $\mathrm{Hh}$ & $-0.42 *$ & -0.08 & -0.09 & $-0.37 *$ & $-0.33^{*}$ & -0.05 & $-0.41^{*}$ \\
\hline CEC & $0.44 *$ & $0.41 *$ & -0.09 & $0.41 *$ & 0.13 & $0.40^{*}$ & $0.53^{*}$ \\
\hline
\end{tabular}

CEC cation exchange capacity, Hh hydrolytic acidity

*Significant at $p \leq 0.05, n=96$

Similarly to its form approximating the total one, the least $\mathrm{Cu}$ soluble in $1 \mathrm{~mol} \mathrm{HCl} / \mathrm{dm}^{3}$ was contained in the control soil and in soil fertilized with mineral fertilizers alone. Organic substances used as soil fertilizers increased the content of the easily soluble form of this element (from $75 \%$ more in soil treated with CUGW and CSS, to $124 \%$ in soil fertilized with CUHW). The smallest amount of easily soluble $\mathrm{Zn}$ was determined in soil fertilized with CUGW (10.52 $\mathrm{mg} / \mathrm{kg})$, and the highest content of this $\mathrm{Zn}$ form was identified in soil fertilized with mineral NPK $(12.11 \mathrm{mg} / \mathrm{kg})$. The smallest amounts of easily soluble $\mathrm{Mn}$ and Fe forms were detected in the soil fertilized with mineral NPK (100.5 and $1170.9 \mathrm{mg} / \mathrm{kg}$, respectively). The highest amount of easily soluble Mn was determined in soil fertilized with CUHW $(113.8 \mathrm{mg} / \mathrm{kg})$, while the highest amount of this Fe $(1961.1 \mathrm{mg} / \mathrm{kg})$ form was found in soil treated with DPSS (13 and 44\% more, respectively, than in soil fertilized with NPK). The content of soluble forms of $\mathrm{Pb}$ and $\mathrm{Ni}$ in soil fertilized with manure was on the same level as in the control soil ( 8.14 and $0.77 \mathrm{mg} / \mathrm{kg}$, respectively). Mineral fertilizers, composts, and, above all, dried pelleted sewage sludge (DPSS) contributed to an increase in the amounts of $1 \mathrm{~mol} \mathrm{HCl} / \mathrm{dm}^{3}$ soluble forms of $\mathrm{Pb}$ and $\mathrm{Ni}$ (by 16 and 44\%, respectively). Organic fertilization raised the content of soluble $\mathrm{Cr}$ in soil, and the highest quantity of this metal $(0.87 \mathrm{mg} / \mathrm{kg})$ was detected in soil treated with manure (by about $32 \%$ more than in the control and NPK-fertilized soils).

The sequential analysis of the $\mathrm{Zn}$ and $\mathrm{Cu}$ content in sewage sludge showed that content of these metals in easily soluble and exchangeable fractions were low, and their highest amounts were bound in organic and residual fractions (Malinowska 2016a, b). After sewage sludge had been introduced to soil and the organic substance had been mineralized, the bioavailability of these metals increased, although it was still low regarding $\mathrm{Cu}$, whose share of easily soluble and exchangeable fractions did not exceed $10 \%$ of the total content. According to Gondek (2010), fertilization with manure and sewage sludge did not cause significant mobilization of mobile $\mathrm{Zn}$ forms in soil in the first year. Due to the mineralization of organic matter and progressing acidification of soil, in the following years, the content of mobile forms of this element increased, but to a lesser extent than under the influence of mineral fertilization. In a study by Bowszys et al. (2015), sewage sludge compost significantly increased the soil content of available forms of $\mathrm{Zn}$ and $\mathrm{Cu}$, but the increase was insufficient to change the soil's classification to a higher category with respect to the abundance of these two elements. On the other hand, the content of $\mathrm{Zn}$ and $\mathrm{Cu}$ in soil leachate depended on the type of applied fertilizers. Most of $\mathrm{Zn}$ was leached from soil fertilized with composted sewage sludge, and most of $\mathrm{Cu}$ was leached from soil fertilized with composted sewage sludge and sewage sludge composted with straw.

Page et al. (2014) claim that soil reaction cannot be treated as a sole indicator of the mobility of heavy metals and their availability to plants, or the risk of their migration to the water environment. Tahervand and Jalali (2016) demonstrated that sorption and desorption of heavy metals in soil depended not only on the soil's pH but also on its content of organic matter and calcium carbonate and on the chemical properties of a given metal. $\mathrm{Cd}$ and $\mathrm{Ni}$ are most strongly adsorbed in soil with a high content of organic matter, while $\mathrm{Fe}$ in soil rich in $\mathrm{CaCO}_{3}$. On the other hand, metals adsorbed by organic matter undergo desorption more easily than ones adsorbed by $\mathrm{CaCO}_{3}$, because sorption on 

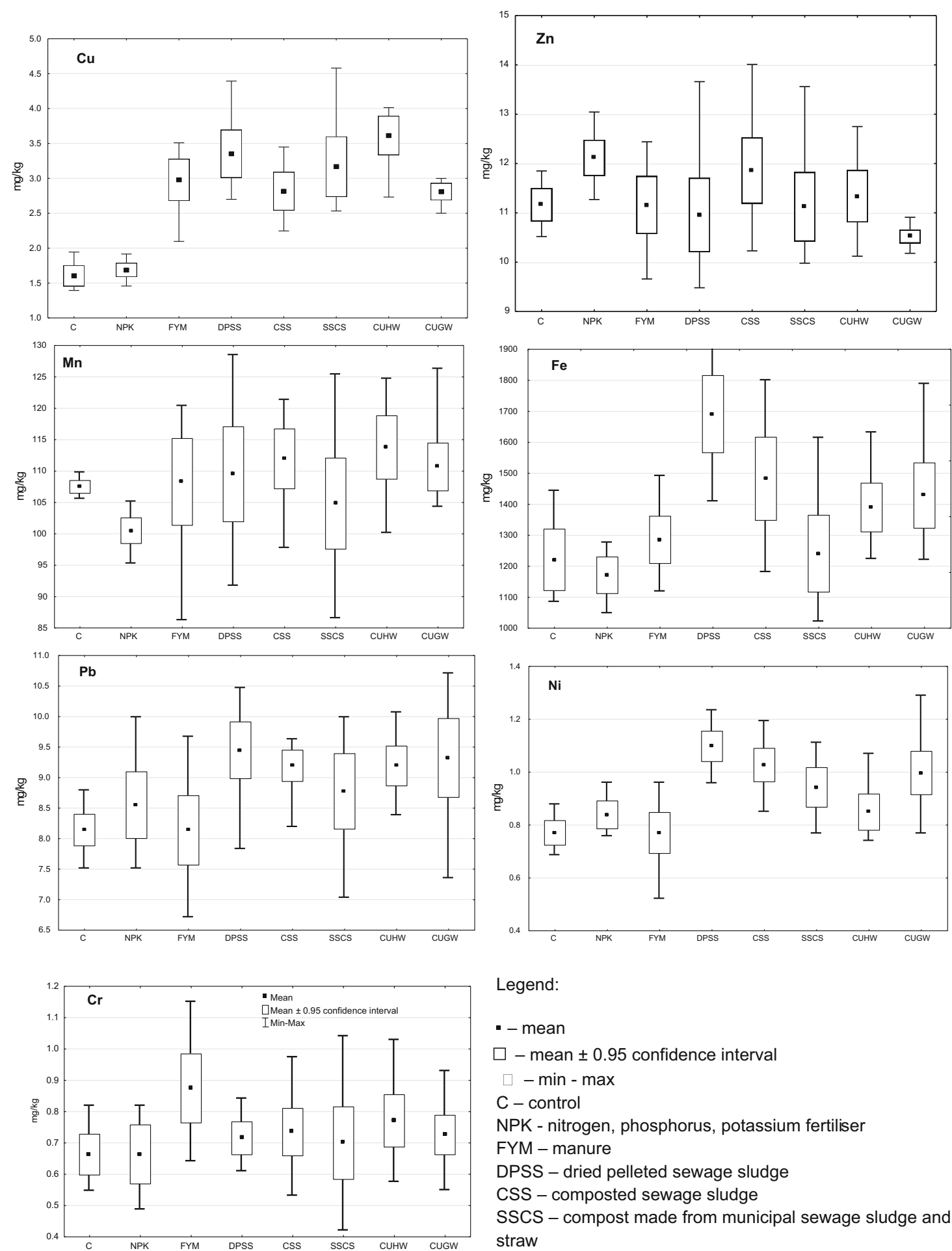

Legend:

- mean

$\square-$ mean \pm 0.95 confidence interval

$\square-\min -\max$

C - control

NPK - nitrogen, phosphorus, potassium fertiliser

FYM - manure

DPSS - dried pelleted sewage sludge

CSS - composted sewage sludge

SSCS - compost made from municipal sewage sludge and straw

CUHW - compost "Dano" made from unsorted household waste

Fig. 2 Soil content of heavy metals soluble in $1 \mathrm{~mol} \mathrm{HCl} / \mathrm{dm}^{3}$. Legend: - mean, $\square$ mean \pm 0.95 confidence interval, min-max, $\mathrm{C}$ control, NPK nitrogen, phosphorus, potassium fertilizer, FYM manure, DPSS dried pelleted sewage sludge, CSS composted

sewage sludge, SSCS compost made from municipal sewage sludge and straw, CUHW compost "Dano" made from unsorted household waste, CUGW compost produced from urban green waste 
Table 5 Correlations coefficient $r$ between selected soil properties and the soil content of heavy metals soluble in $1 \mathrm{~mol} \mathrm{HCl} / \mathrm{dm}^{3}$

\begin{tabular}{lccccccc}
\hline Selected soil properties & \multicolumn{2}{l}{ Content of heavy metals in soil } & & & \\
\cline { 2 - 7 } & $\mathrm{Cu}$ & $\mathrm{Zn}$ & $\mathrm{Mn}$ & $\mathrm{Fe}$ & $\mathrm{Pb}$ & $\mathrm{Ni}$ & $\mathrm{Cr}$ \\
\hline $\mathrm{nyH}$ & $0.56^{*}$ & 0.11 & $0.22^{*}$ & $0.25^{*}$ & $0.40^{*}$ & 0.01 & $0.50^{*}$ \\
$\mathrm{C}$-org. & $0.80^{*}$ & -0.09 & $0.37^{*}$ & $0.55^{*}$ & $0.50^{*}$ & $0.45^{*}$ & $0.23^{*}$ \\
P-tot. & $0.44^{*}$ & $-0.27^{*}$ & -0.13 & -0.15 & 0.02 & $0.23^{*}$ & -0.16 \\
Hh & $-0.46^{*}$ & 0.07 & $-0.21^{*}$ & -0.05 & $-0.31^{*}$ & -0.07 & -0.11 \\
CEC & $0.36^{*}$ & 0.10 & 0.01 & 0.16 & $0.36^{*}$ & 0.12 & $0.24^{*}$ \\
\hline
\end{tabular}

CEC cation exchange capacity, $H h$ hydrolytic acidity

*Significant at $p \leq 0.05, \mathrm{n}=96$

carbonate minerals is often dominated by strong chemical reactions. Kopeć et al. (1991) suggest that organic fertilization leads to weaker penetration of trace elements deep into the soil profile. Another factor which influences the mobility of heavy metals is the maturity of compost added to soil. Fresh composts with a high content of low molecular organic acids may induce the mobilization of heavy metals present in both the applied compost and the soil (Zmora-Nahum et al. 2005; Weber et al. 2007). Sewage sludge added to soil cause changes in the soil mobility of heavy metals (Malinowska 2016a, $b, 2017)$. As a result of the mineralization of organic matter, the mobility of heavy metals improves, whereas soil liming favors their binding in the residual fraction. According to Kuziemska et al. (2014), it is not only soil liming but also organic matter in the soil that are responsible for decreased mobility of nickel in soil. MamindyPajany et al. (2013) claim that soluble organic carbon contained in sewage sludge applied to limestone soils can facilitate the leaching of $\mathrm{Ni}$ by creating soluble $\mathrm{Ni}$ - organic complexes. Moretti et al. (2016) showed that short-term application of sewage sludge and sewage sludge composts with low levels of heavy metals, tested in the tropical rainforest conditions, did not have negative effects on soil. The content of heavy metals remained below the maximum acceptable threshold values and approximated the geochemical background values reported for the research area. Sewage sludge composts introduced to soil cause changes in the soil mobility of metals. Sewage sludge composts led to a lower increase in the content of $\mathrm{Cu}$ and $\mathrm{Ni}$ in soil than sewage sludge did.

In this research, the content of the selected heavy metals soluble in $1 \mathrm{~mol} \mathrm{HCl} / \mathrm{dm}^{3}$, except $\mathrm{Ni}$ and $\mathrm{Zn}$, was significantly positively correlated with the soil $\mathrm{pH}$, whereas the soil content of C-org. left unaffected only the content of $\mathrm{Zn}$ in soil (Table 5). The content of $\mathrm{Cu}$ and Ni soluble in $1 \mathrm{~mol} \mathrm{HCl} / \mathrm{dm}^{3}$ was significantly positively correlated with P-tot. content in the soil $\left(r=0.44^{*}\right.$ and $r=0.23^{*}$, respectively). In turn, the content of soluble

Table 6 Correlations coefficient $r$ between the selected properties of organic materials and the soil's content of heavy metals soluble in $1 \mathrm{~mol} \mathrm{HCl} / \mathrm{dm}^{3}$

\begin{tabular}{|c|c|c|c|c|c|c|c|c|c|c|}
\hline \multirow{2}{*}{ Content of heavy metals in soil } & \multicolumn{10}{|c|}{ Selected properties of organic materials } \\
\hline & C-org & $\mathrm{C} / \mathrm{N}$ & P-tot. & $\mathrm{Cu}$ & $\mathrm{Zn}$ & $\mathrm{Mn}$ & $\mathrm{Fe}$ & $\mathrm{Pb}$ & $\mathrm{Ni}$ & $\mathrm{Cr}$ \\
\hline $\mathrm{Cu}$ & 0.02 & $0.30 *$ & -0.08 & $0.39 *$ & & & & & & \\
\hline $\mathrm{Zn}$ & 0.21 & 0.09 & 0.21 & & -0.06 & & & & & \\
\hline $\mathrm{Mn}$ & 0.02 & 0.08 & 0.05 & & & 0.06 & & & & \\
\hline $\mathrm{Fe}$ & $0.44^{*}$ & $-0.31^{*}$ & $0.43 *$ & & & & $0.26^{*}$ & & & \\
\hline $\mathrm{Pb}$ & 0.09 & $-0.25^{*}$ & $0.26^{*}$ & & & & & 0.21 & & \\
\hline $\mathrm{Ni}$ & $0.35^{*}$ & $-0.62 *$ & $0.58 *$ & & & & & & -0.21 & \\
\hline $\mathrm{Cr}$ & -0.04 & $0.28 *$ & $-0.24 *$ & & & & & & & 0.01 \\
\hline
\end{tabular}

*Significant at $p \leq 0.05, n=72$ 
Table 7 Share of forms soluble in $1 \mathrm{~mol} \mathrm{HCl} / \mathrm{dm}^{3}$ in the total content of heavy metals in soil

\begin{tabular}{|c|c|c|c|c|c|c|c|}
\hline Experimental object & $\begin{array}{l}\mathrm{Cu} \\
\%\end{array}$ & $\mathrm{Zn}$ & $\mathrm{Mn}$ & $\mathrm{Fe}$ & $\mathrm{Pb}$ & $\mathrm{Ni}$ & $\mathrm{Cr}$ \\
\hline Control (C) & $37.57^{\mathrm{a}^{*}}$ & $74.51^{\mathrm{d}}$ & $56.87^{\mathrm{ab}}$ & $28.01^{\mathrm{ab}}$ & $55.80^{\mathrm{ab}}$ & $11.61^{\mathrm{cd}}$ & $5.36^{\mathrm{a}}$ \\
\hline NPK & $39.97^{\mathrm{a}}$ & $80.90^{\mathrm{e}}$ & $53.07^{\mathrm{b}}$ & $26.96^{\mathrm{ab}}$ & $58.68^{\mathrm{ab}}$ & $12.64^{\text {ad }}$ & $5.40^{\mathrm{a}}$ \\
\hline Manure (FYM) & $61.01^{\mathrm{c}}$ & $61.89^{\mathrm{bc}}$ & $61.35^{\mathrm{c}}$ & $28.80^{\mathrm{a}}$ & $54.46^{\mathrm{a}}$ & $9.97^{\mathrm{b}}$ & $6.34^{\mathrm{b}}$ \\
\hline Dried pelleted sewage sludge (DPSS) & $54.81^{\mathrm{bc}}$ & $55.37^{\mathrm{a}}$ & $55.07^{\mathrm{ab}}$ & $36.59^{\mathrm{d}}$ & $57.41^{\mathrm{ab}}$ & $13.79^{\mathrm{a}}$ & $5.19^{\mathrm{a}}$ \\
\hline Composted sewage sludge (CSS) & $50.36^{\mathrm{b}}$ & $65.47^{\mathrm{c}}$ & $58.30^{\mathrm{a}, \mathrm{c}}$ & $32.09^{\mathrm{c}}$ & $60.47^{\mathrm{b}}$ & $13.15^{\mathrm{a}}$ & $4.90^{\mathrm{a}}$ \\
\hline Compost made from municipal sewage sludge and straw (SSCS) & $51.93^{\mathrm{b}}$ & $56.89^{\mathrm{a}}$ & $57.28^{\mathrm{a}-\mathrm{c}}$ & $25.66^{\mathrm{b}}$ & $59.20^{\mathrm{ab}}$ & $12.97^{\mathrm{a}}$ & $5.27^{\mathrm{a}}$ \\
\hline Compost "Dano" made from unsorted household waste (CUHW) & $59.9^{6 \mathrm{c}}$ & $55.83^{\mathrm{a}}$ & $58.08^{\mathrm{a}, \mathrm{c}}$ & $29.55^{\mathrm{a}, \mathrm{c}}$ & $56.29 \mathrm{ab}$ & $10.87^{\mathrm{bc}}$ & $4.98^{\mathrm{a}}$ \\
\hline Compost produced from urban green waste (CUGW) & $42.41^{\mathrm{a}}$ & $59.33^{\mathrm{ab}}$ & $56.12^{\mathrm{ab}}$ & $29.66^{\mathrm{a}, \mathrm{c}}$ & $57.08^{\mathrm{ab}}$ & $13.54^{\mathrm{a}}$ & $4.74^{\mathrm{a}}$ \\
\hline
\end{tabular}

*Data designated with same letters do not differ significantly at $p \leq 0.05$

forms of $\mathrm{Zn}$ was negatively correlated $\left(r=-0.27^{*}\right)$ with the content of P-tot. in the soil. A significant positive dependence was also confirmed between the capacity of the sorption complex and the soil's content of easily soluble forms of $\mathrm{Cu}, \mathrm{Pb}$, and $\mathrm{Cr}$. The content of $\mathrm{Cu}$, $\mathrm{Pb}$, and $\mathrm{Mn}$ soluble in $1 \mathrm{~mol} \mathrm{HCl} / \mathrm{dm}^{3}$ was significantly negatively correlated with the hydrolytic acidity of soil.

The content of heavy metals soluble in $1 \mathrm{~mol} \mathrm{HCl} /$ $\mathrm{dm}^{3}$ also depended on the properties of organic materials used for soil fertilization (Table 6). The amount of easily soluble $\mathrm{Cu}$ was positively correlated with the $\mathrm{C} / \mathrm{N}$ ratio $\left(r=0.30^{*}\right)$ and the content of $\mathrm{Cu}$ in organic materials $\left(r=0.39^{*}\right)$. In turn, the content of the mobile forms of $\mathrm{Fe}$ and $\mathrm{Ni}$ was positively correlated with the content of C-org. ( $r=0.44^{*}$ and $r=0.35^{*}$, respectively) and Ptot. $\left(r=0.43^{*}\right.$ and $0.58^{*}$, respectively). Also, the content of $\mathrm{Fe}$ in organic materials had a significant influence $\left(r=0.26^{*}\right)$ on the amount of its easily soluble form in soil. The quantities of $\mathrm{Fe}, \mathrm{Pb}$, and $\mathrm{Ni}$ forms soluble in $1 \mathrm{~mol} \mathrm{HCl} / \mathrm{dm}^{3}$ were negatively correlated $\left(r=-0.31^{*}\right.$, $r=-0.25^{*}$, and $r=-0.62^{*}$, respectively) with changes in the $\mathrm{C} / \mathrm{N}$ ratio in organic materials, whereas the content of easily soluble $\mathrm{Cr}$ changed proportionally $(r=$ $\left.0.28^{*}\right)$ to changes in the $\mathrm{C} / \mathrm{N}$ ratio. The content in soil of mobile forms $\mathrm{Pb}$ was positively correlated $\left(r=0.26^{*}\right)$, whereas the content of $\mathrm{Cr}$ easily soluble in soil was negatively correlated $\left(r=-0.24^{*}\right)$ with the content of P-tot. in organic materials.

According to Czarnowska and Kozanecka (2001), the content of soluble forms of $\mathrm{Zn}, \mathrm{Cu}$, and $\mathrm{Cd}$ in the soil's humic horizon is highly significantly correlated with the total content of all forms of these metals in soil. The share of soluble forms in the total content of these metals decreased in the following order: $\mathrm{Zn}>\mathrm{Cd}>\mathrm{Cu}>$ $\mathrm{Pb}>\mathrm{Ni}$.

The data shown in Table 7 show that the shares of forms soluble in $1 \mathrm{~mol} \mathrm{HCl} / \mathrm{dm}^{3}$ in the total content of heavy metals were as follows: $\mathrm{Zn}(63.77 \%)>\mathrm{Pb}$ $(57.42 \%)>\mathrm{Mn}(57.02 \%)>\mathrm{Cu}(49.75 \%)>\mathrm{Fe}>$ $(29.67 \%)>\mathrm{Ni}(12.32 \%)>\mathrm{Cr}(5.27 \%)$. The smallest share of $\mathrm{Cu}$ soluble in $1 \mathrm{~mol} \mathrm{HCl} / \mathrm{dm}^{3}$ was determined in control soil and in soil fertilized exclusively with
Fig. 3 Dendrogram of the content of heavy metals in soil. C control; NPK nitrogen, phosphorus, potassium mineral fertilizer; FYM manure; DPSS dried pelleted sewage sludge; CSS composted sewage sludge; SSCS compost made from municipal sewage sludge and straw; CUHW compost "Dano" made from unsorted household waste; CUGW compost produced from urban green waste

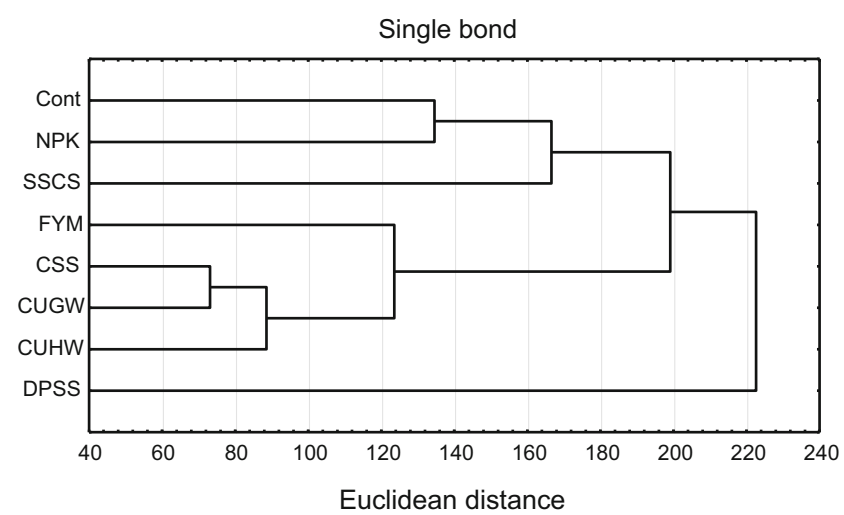


mineral fertilizers (37.57 and 39.97\%, respectively). The organic materials added to soil, and particularly manure (FYM) and compost from unsorted municipal waste (CUHW), increased the share of soluble $\mathrm{Cu}$ forms. With respect to $\mathrm{Zn}$, the highest share of this form of $\mathrm{Zn}$ was determined in the NPK-fertilized soil $(80.90 \%)$, whereas manure (FYM), sewage sludge, and composts decreased the percentage of this form of Zn compared to soil fertilized with NPK mineral fertilizers and to the control soil. In the case of $\mathrm{Mn}$, the share of easily soluble forms in its total content ranged from $53.07 \%$ in soil fertilized with NPK mineral fertilizers alone to $61.35 \%$ in soil fertilized with manure. The smallest share of easily soluble $\mathrm{Fe}$ was determined in soil fertilized with sewage sludge composted with straw $(25.66 \%)$ and the highest one was identified in soil fertilized with DPSS (36.59\%). The smallest solubility of $\mathrm{Pb}$ compounds $(54.46 \%)$ was noted in soil fertilized with manure, while CSS significantly increased the share of soluble forms of this element. Similarly to $\mathrm{Pb}$, the smallest share of soluble $\mathrm{Ni}$ forms was found in manure-treated soil. Sewage sludge and sewage sludge composts as well as compost made from urban green (CUGW) waste significantly raised the solubility of $\mathrm{Ni}$ compounds. Same as in the case of $\mathrm{Cu}$ and $\mathrm{Mn}$, the highest share of $\mathrm{Cr}$ soluble forms was determined in soil fertilized with manure.

According to Sienkiewicz and Czarnecka (2012), in alkaline soils, an increase in the content of soluble forms of $\mathrm{Cu}, \mathrm{Zn}$, and $\mathrm{Mn}$ in soil fertilized with large doses of sewage sludge (up to $280 \mathrm{t} / \mathrm{ha}$ ), rather than being a threat to the environment, improved the nutrition of plants with these micronutrients. In another study by Sienkiewicz et al. (2009), it was demonstrated that regular manure fertilization increased the content of $\mathrm{Cu}, \mathrm{Zn}$, and $\mathrm{Mn}$ soluble forms compared to soil which received only mineral fertilization.

Nutrients applied in doses exceeding the requirements of plants lead to a change in the ionic equilibrium of the soil solution and to the leaching of these elements to groundwater (Gondek 2009). A single application of a dose of sewage sludge, even a large one, does not cause a distinct rise in the leaching of heavy metals from soil, when compared to the application of manure or even NPK mineral fertilization. However, due to the positive balance of these elements in soil, long-term use of sewage sludge may be problematic, especially when soil acidity increases, in the consequence of which the mobility of elements and their leachability rise
(Sevel et al. 2014). In a study conducted by Wierzbowska et al. (2016), soil fertilization with organic waste did not pollute leachate water with $\mathrm{Mn}$ and $\mathrm{Zn}$, while content of other metals rose to a level typical of unsatisfactory or even poor quality water. The content of $\mathrm{Cu}$ and $\mathrm{Ni}$ in leachate water depended on the quantities of other metals imported to soil with organic materials, for example, content of $\mathrm{Cu}$ and $\mathrm{Ni}$ decreased as the content of C-org. in fertilizers increased. Moreover, contents of $\mathrm{Pb}, \mathrm{Cr}$, and $\mathrm{Mn}$ in percolating water were positively correlated with the content of organic carbon on soil, and a higher $\mathrm{C} / \mathrm{N}$ ratio contributed to the leaching Mn. According to Kalembasa and Pakuła (2009), incorporation of sewage sludge into soil increased the content of $\mathrm{Zn}, \mathrm{Cr}, \mathrm{Ni}, \mathrm{Pb}$, and $\mathrm{Cu}$ in the exchangeable fraction, reducing the fraction bound with $\mathrm{Fe}$ and $\mathrm{Mn}$ oxides and the oxidizing-organic fraction, while decreasing their content in the residual fraction. The shares of heavy metals in particular fractions largely depended on the content of organic carbon and the clay fraction, being less dependent on the total content of a given element in soil and soil sorption capacity.

Results of the cluster analysis enabled us to distinguish groups of fertilization objects with approximately the same content of heavy metals in soil (Fig. 3). The most similar content of these elements was found in soil fertilized with SSC and with CUGW. The content of these metals in soil fertilized with CUHW was only slightly different from their content in soil fertilized with SSC and CUGW. Another group consisted of control soil and NPK-fertilized soil. The content of heavy metals in soil fertilized with DPSS differed to the highest extent from their content in soil sampled from the other treatments.

\section{Conclusion}

The experiment was conducted in a region free from the risk of soil pollution with heavy metals originating from industries. Moreover, the tested soil had developed from soil material poor in these elements. In compliance with the Polish law, the amounts of heavy metals observed in our study (forms close to the total content) were within the limits of their natural content in the superficial soil layer. It is therefore justifiable to claim that the tested waste substances and composts as well as NPK or manure applied in moderate doses do not create a risk of excessive accumulation of heavy metals in average 
soil. The content of available forms of trace metals, which are considered to be micronutrients owing to the roles they play in life processes $(\mathrm{Cu}, \mathrm{Zn}, \mathrm{Mn}$, and $\mathrm{Fe})$, was not high. On the contrary, the soil richness in micronutrients was within the range of unsatisfactory to medium. The content of all the analyzed heavy metals in soil (forms close to the total) was significantly positively correlated with the content of organic carbon (Corg.). In turn, the content of available forms of heavy metals was more strongly dependent on the soil $\mathrm{pH}$ than on its content of C-org. This set of relationships clearly demonstrates that even an elevated content of heavy metals in soil may not be a threat as long as an appropriate soil reaction is maintained.

Funding information This research was supported by the Ministry of Science and Higher Education of Poland as the part of statutory activities.

Open Access This article is distributed under the terms of the Creative Commons Attribution 4.0 International License (http:// creativecommons.org/licenses/by/4.0/), which permits unrestricted use, distribution, and reproduction in any medium, provided you give appropriate credit to the original author(s) and the source, provide a link to the Creative Commons license, and indicate if changes were made.

\section{References}

Bowszys, T., Wierzbowska, J., Bowszys, J., \& Bieniek, A. (2009). Modifications in the content of available zinc and copper in soil fertilized with bio-waste compost. Journal of Elementology, 14(1), 33-42.

Bowszys, T., Wierzbowska, J., Sternik, P., \& Busse, M. K. (2015). Effect of the application of sewage sludge compost on the content and leaching of zinc and copper from soils under agricultural use. Journal of Ecological Engineering., 16(1), 1-7. https://doi.org/10.12911/22998993/580.

Czarnowska, K., \& Kozanecka, T. (2001). Soluble forms of heavy metals in anthropogenic soils of Warsaw area. Roczniki Gleboznawcze, 52(3/4), 45-51 (in Polish).

Environment (2016). Central statistical office, Warszawa (in Polish).

Fadiran, A. O., Tiruneh, A. T., \& Mtshali, J. S. (2014). Assessment of mobility and bioavailability of heavy metals in sewage sludge from Swaziland through speciation analysis. American Journal of Environmental Protection, 3(4), 198208. https://doi.org/10.11648/j.ajep.20140304.14.

Gawdzik, J., \& Gawdzik, B. (2012). Mobility of heavy metals in municipal sewage sludge from different throughput sewage treatment plants. Polish Journal of Environmental Studies, 21(6), 1603-1611.

Gondek, K. (2009). The effect of fertilization on the content of mobile forms of selected microelements in soil and their leaching in a pot experiment. Acta Agrophysica, 13(1), 89101 (in Polish).

Gondek, K. (2010). Zinc and cadmium accumulation in maize (Zea mays L.) and the concentration mobile forms of these metals in soil after application of farmyard FYM and sewage sludge. Journal of Elementology, 15(4), 639-652.

Introduction of Fertilizers on the Commercial Market. (n.d.) http://www.iung.pulawy.pl/index.php?option=com content\&view $=$ article \&id=99\&Itemid=61 (in Polish).

IUSS WORKING GROUP WRB (2015). World Reference Base for Soil Resources 2014. International soil classification system for naming soils and creating legends for soil maps. Update 2015. World Soil Resources Reports 106. FAO Rome, 188 pp.

Kabata-Pendias, A., \& Pendias, H. (1999). Biogeochemistry of trace elements. Publisher: Wydawnictwo Naukowe PWN, pp. 400 (in Polish).

Kalembasa, D., \& Pakuła, K. (2009). Heavy metal fractions in soils fertilized with sewage sludge. Environment Protection Engineering, 35(2), 157-164.

Karczewska, A., \& Kabała, C. (2008). Metodyka analiz laboratoryjnych gleb i roślin. UP Wrocław. http://www.ar. wroc.pl/ kabal (in Polish).

Kluczka, J., Zołotajkin, M., Ciba, J., \& Staroń, M. (2017). Assessment of aluminum bioavailability in alum sludge for agricultural utilization. Environmental Monitoring and Assessment, 189, 422. https://doi.org/10.1007/s10661-0176133-x.

Kopeć, M., Nowak, K., \& Smoroń, S. (1991). Losses of fertilizing elements due to leaching depending on fertilization and crop kind. Roczniki Gleboznawcze, 52(3/4), 104-114 (in Polish).

Kuziemska, B., Kalembasa, S., \& Wieremiej, W. (2014). Distribution of nickel in fractions extracted with the BCR procedure from nickel-contaminated soil. Journal of Elementology, 19(3), 697-670. https://doi.org/10.5601 /jelem.2014.19.3.702.

Malinowska, E. (2016a). The effects of soil liming and sewage sludge application on dynamics of copper fractions and total copper concentration. Environmental Monitoring and Assessment, 188, 597. https://doi.org/10.1007/s10661-0165609-4.

Malinowska, E. (2016b). Zinc speciation in soil under various rates of sewage sludge and liming. Environment Protection Engineering, 42(4), 5-15. https://doi.org/10.5277 /epe160401.

Malinowska, E. (2017). The effect of liming and sewage sludge application on heavy metal speciation in soil. Bulletin of Environmental Contamination and Toxicology, 98, 105112. https://doi.org/10.1007/s00128-016-1984-3.

Mamindy-Pajany, Y., Sayen, S., \& Guillon, E. (2013). Impact of sewage sludge spreading on nickel mobility in a calcareous soil: adsorption-desorption through column experiments. Environmental Science and Pollution Research, 20(7), 4414-4423. https://doi.org/10.1007/s11356-012-1357-3.

Milinovic, J., Vidal, M., Lacorte, S., \& Rigol, A. (2014). Leaching of heavy metals and alkylphenolic compounds from fresh and dried sewage sludge. Environmental Science and Pollution Research, 21, 2009-2017. https://doi.org/10.1007 /s11356-013-2100-4.

Moretti, S. M., Bertoncini, E. I., Vitti, A. C., Alleoni, L. R., \& Abreu-Junior, C. H. (2016). Concentration of $\mathrm{Cu}, \mathrm{Zn}, \mathrm{Cr}, \mathrm{Ni}$, 
$\mathrm{cd}$, and $\mathrm{Pb}$ in soil, sugarcane leaf and juice: residual effect of sewage sludge and organic compost application. Environmental Monitoring and Assessment, 188, 163. https://doi.org/10.1007/s10661-016-5170-1.

Ostrowska, A., Gawliński, A., \& Szczubiałka, Z. (1991). Methods of analysis and assessment of soil and plant properties. Warszawa: Instytut Ochrony Środowiska, p. 1-324.

Page, K., Harbottle, M. J., Cleall, P. J., \& Hutchings, T. R. (2014). Heavy metal leaching and environmental risk from the use of compost-like output as an energy crop growth substrate. Science of the Total Environment, 487, 260-271. https://doi. org/10.1016/j.scitotenv.2014.04.021.

Park, J. H., Lamb, D., Paneerselvam, P., Choppala, G., Bolan, N., \& Chung, J. W. (2011). Role of organic amendments on enhanced bioremediation of heavy metal(loid) contaminated soils. Journal of Hazardous Materials, 185(2), 549-574. https://doi.org/10.1016/j.jhazmat.2010.09.082.

Regulation of the Minister for the Environment on municipal sewage sludge, of 6 February 2015, Dz.U. 2015 item 257 (in Polish).

Sevel, L., Ingerslev, M., Nord-Larsen, T., Jørgensen, U., Holm, P. E., \& Schelde, K. (2014). Fertilization of SRC willow, II: leaching and element balances. Bioenergy Research, 7, 338352. https://doi.org/10.1007/s12155-013-9370-z.

Sienkiewicz, S., \& Czarnecka, M. (2012). Content of available C, $\mathrm{Zn}$ and $\mathrm{Mn}$ in soil amended with municipal sewage sludge. Journal of Elementology, 17(4), 649-657. https://doi. org/10.5601/jelem.2012.17.4.08.

Sienkiewicz, S., Wojnowska, T., Krzebietke, S., Wierzbowska, J., \& Żarczyński, P. (2009). Content of available forms of some micronutrients in soil after long-term differentiated fertilization. Journal of Elementology, 14(4), 787-794.
Tahervand, S., \& Jalali, M. (2016). Sorption, desorption, and speciation of $\mathrm{Cd}, \mathrm{Ni}$, and $\mathrm{Fe}$ by four calcareous soils as affected by $\mathrm{pH}$. Environmental Monitoring and Assessment, 188, 322. https://doi.org/10.1007/s10661-016-5313-4.

Tytła, M., Widziewicz, K., \& Zielewicz, E. (2016). Heavy metals and its chemical speciation in sewage sludge at different stages of processing. Environmental Technology, 37(7), 899-908. https://doi.org/10.1080/09593330.2015.1090482.

Weber, J., Karczewska, A., Drozd, J., Licznar, M., Licznar, S., Jamroz, E., \& Kocowicz, A. (2007). Agricultural and ecological aspects of sandy soil fertility as affected by the application of composts produced from municipal solid wastes. Soil Biology and Biochemistry, 39(6), 1294-1302. https://doi.org/10.1016/j.soilbio.2006.12.005.

Wieczorek, J., \& Frączek, K. (2013). Assessment of possibility of agricultural use of municipal sewage sludge generated in selected small sewage treatment plants from Kraków district. Journal of Ecological Engineering, 14(2), 36-42. https://doi. org/10.5604/2081139X.1043179.

Wierzbowska, J., Sienkiewicz, S., Krzebietke, S., \& Bowszys, T. (2016). Heavy metals in water percolating through soil fertilized with biodegradable waste materials. Water, Air, \& Soil Pollution, 227, 456. https://doi.org/10.1007/s11270-0163147-x.

Wu, L.H., Luo, Y.M., Christie, P. \&, Wong, M.H. (2003). Effects of EDTA and low molecular weight organic acids on soil solution properties of a heavy metal polluted soil. Chemosphere, 50(6), 819-822. https://doi.org/10.1016 /S0045-6535(02)00225-4

Zmora-Nahum, S., Markovitch, O., Tarchitzky, J., \& Chen, Y. (2005). Dissolved organic carbon (DOC) as a parameter of compost maturity. Soil Biology and Biochemistry, 37(11), 2109-2116. https://doi.org/10.1016/j.soilbio.2005.03.013. 